2. Datsij, O. I. (2004). Rozvytok innovatsiynoyi diyal'nosti v ahropromyslovomu vyrobnytstvi Ukrayiny [Development of innovative activity in agroindustrial production of Ukraine]. NNTs IAE, Kyiv.

3. Zubariev, A. S., Yemelianov, S. H., \& Borysohlibskyi, L. N. (2010). Stvorennya rehional'noyi innovatsiynoyi systemy ye pokaznykom stiykoho rozvytku ekonomiky rehionu [The creation of a regional innovation system is an indicator of the sustainable development of the region's economy]. Economy and the state. Vol. 7. P. 59-63.

4. Matrosova, V. O. (2013). Suchasni teoretychni ta metodychni pidkhody do otsinky efektyvnosti vykorystannya innovatsiynoho potentsialu pidpryyemstva [Modern theoretical and methodical approaches to assessing the effectiveness of using innovative potential of the enterprise]. Visnyk NTU «KhPI». Vol. 66 (1036). P. 86-96.

5. Tolbatov, A. V. (2018). Naukove seredovyshche suchasnoyi lyudyny: ekonomika, menedzhment, medytsyna ta farmatsevtyka, khimiya, biolohiya, sil's'ke hospodarstvo, heohrafiya ta heolohiya. [The scientific environment of modern man: Economics, Management, Medicine and Pharmaceuticals, Chemistry, Biology, Agriculture, Geography and Geology: monograph]. Odessa.

\title{
ADAPTIVE PROPERTIES OF MAIZE FORMS FOR IMPROVEMENT IN THE ECOLOGICAL STATUS OF FIELDS
}

\section{Artem Maksymenko ${ }^{1}$ Kristina Tsigelnik ${ }^{2}$}

DOI: https://doi.org/10.30525/978-9934-588-11-2_6

Maize is a dominant crop in the world's total grain production. Approximately 850 million tons of maize, with an average yield of $5.2 \mathrm{t} / \mathrm{ha}$, are produced on the total area of 162 million hectares. In more recent times, the production of this crop grain has increased at a record pace up to 850 million tons in the world, and 39.0$46.2 \%$ of it is harvested in the United States, the high gross yield is observed in China and Brazil as well.

In Ukraine, 4.5-5.0 million hectares are occupied by maize that is almost a quarter of all grain crops. Grain maize is grown on 4.0-4.5 million hectares, maize for silage and green fodder - on 0.2-0.4 million hectares [1, p. 783-790; 3, p. 40-45]. The introduction of intensive technology and new high-performance hybrids into production has significantly increased the yield of maize on large areas. Many of the best farms obtain 9-10 t/ha or more, including in new maize-growing areas (Polissia of Ukraine). In some regions of Ukraine, the yield is amounted to 4.5-6.0 t/ha, but in general in Ukraine the volume of maize yield remains low, including as a consequence of entomopathogens and phytopathogens [1, p. 783-790].

According to the long-term data, the total shortfall in maize grain production caused by stem rot, smut, kernel rot and European com borer is estimated at an average of $30.9 \%$.

\footnotetext{
${ }^{1}$ Sumy National Agrarian University, Ukraine

${ }^{2}$ Sumy National Agrarian University, Ukraine
} 
This a reason that the search for sources of resistance to these diseases and pests is particularly relevant, and the creation of maize hybrids with a group character of resistance to major diseases and pests remain one of the main practical tasks of the breeding of maize plant.

An increase in maize grain production is possible primarily due to the limitation of losses during harvesting. Annual losses of grain yield from the lodging of maize plants reach $20 \%$, and in some cases, especially with stem breakage, up to $20-40 \%$ of the crop [2, p. 134-137].

The goal of our research is to determine the effectiveness of the use of maize lines various in genetic basis and resistance to diseases and pests.

The selection of parents for the generation of heterosis is crucial in the breeding of hybrid vigor. The maximum effect of heterosis is achieved only by the hybridization of specially selected lines.

The relevant material was used and the principles of choosing self-pollinated lines for the selection of hybrids in this direction were developed in order to create highyielding maize hybrids resistant to diseases and pests $[5$, p. 5-8].

The 125 forms resistant to boil smut, of which only $9.2 \%$ were characterized by the stability of this character, were distinguished from the studied self-pollinated maize lines. The variation in the resistance of lines and hybrids by years is explained by the different distribution of climatic factors during the period of the greatest susceptibility of plants.

Based on the results of our research, it was found that among the diseases, the greatest harm to the maize breeding material was caused by boil and head smut in the experimental areas. The results of studying the resistance of self-pollinated lines of different origin to the infestation with boil smut indicate that the breeding material studied in the conditions of natural infectious background, regardless of the ripeness group, is highly resistant to this disease.

However, the early ripening lines F 101, MA 11 and mid-ripening lines UHK 411 had a high level of resistance, and the mid-early lines SO 255, UHK 372, HLG 293, HLG 998 and mid-ripening lines SO 113, KL 17, HLG 45 were characterized by low resistance to the infestation with boil smut.

The resistance of simple maize hybrids to the infestation with boil smut depended on the parent components which took part in the crossing, and a heterosis effect. The following samples characterized by high resistance to the disease were selected among the hybrid combinations of different ripeness groups:

early ripening - HLG 81 x HLG 272, HLG 272 x HLG 81, PLS 61 x HLG 562;

mid-early - HLG 1278 x HLG 1216, KL 13 x UHK 411, HLG 33 x HLG 163, SO 108 x MA 22, UHK 409 x MA 22, SM5-1-1 x KL 17, UHK 411 x KL 13, HLG 1216 x HLG 1278, UHK 409 x F 502, MA 22 x F 502, SM 5-1-1 x SO 108, UHK 409 x SM 5-1-1, F 502 x SO 108, SO 108 x F 502, HLG 1339 x HLG 1128, F 502 x MA 22, F 502 x SM 5-1-1, UH 405 x F 502, HLG 1128 x HLG 1339, HLG 562 x PLS 61, HLG 294 x HLG 293, UH 405 x SM 5-1-1.

mid-ripening - SO 108 x UH 405, DK 44-1 x HLG 42, F 502 x UHK 409, UH 405 x SO 108, HLG 42 x DK 44-1, UHK 409 x UH 405, KL 17 x UH 405, UHK 409 x 
SO 108, SO 113 x AS 77-4-1, MA 22 x UH 405, UH 405 x UHK 409, SM 5-1-1 x UH 405, B 37 x MA61A37, F 502 x UH 405.

Other simple hybrids were characterized by medium and low resistance to the infestation with boil smut. It should be noted that if such lines as SO 255 and KL 17 took part in crossing, the resistance of hybrid combinations was low.

In support of these statements, a number of researchers [6, p. 103-105] note that the resistance of maize to $U$. Zeae is a rather complicated feature, which is determined by the anatomical and morphological, and physiological and biochemical characters of plants that are controlled by genetic factors in the system of plant- host pathogen - environment. Many authors point to the significant variability of immunological properties of lines and hybrids to boil smut depending on the year and place of testing. Most of them explain this fact by the difference in environmental conditions. On the other hand, the stability of resistance of lines and hybrids to $U$. zeae depends heavily on the ability of the parasite to change its pathogenicity under the influence of various factors [7, p. 64-66].

The results of studying the resistance of self-pollinated lines to the infestation with boil smut indicate that the breeding material studied in the conditions of natural infectious background, regardless of the ripeness group, is highly resistant to this disease. Thus, we recommend to use such lines as SO 255, KL 17, SO 113, HLG 45 for the breeding of maize resistant to head smut.

During the test years, the infestation of maize plants with head smut under the field conditions was not found. Against the provocative background the plants infested with Sorosporium reilianum were found in 2017. In the hybrid combination of S0255 x KL 17, the infestation was equal to 9.5\%. In 2017, the maize lines and hybrids were infested with head smut to a greater extent on the breeding plot. This was obviously facilitated by the accumulation of infection in the soil and the weather conditions favorable for the spread of the disease.

The majority of the studied lines have turned out to be resistant to head smut, and only such lines as SO 255, KL 17, SO 113 and HLG 45 were affected by this disease. Among dialele hybrids, the share of those infested with the pathogens of head smut is equal to $11.1 \%$, with the lines as one of the parental forms of these hybrids. The genotypic differences in resistance to diseases and pests in self-pollinated lines open the potential for the effective selection of forms with integrated resistance, and their use in hybridization will enable to obtain hybrids resistant to a set of diseases and pests.

The authors have distinguished the self-pollinated lines with integrated resistance to major pests and diseases, namely: HLG 81, HLG 224, F 502, K 210, HLG 163, HLG 189, HLG 1216, HLG 562, K 212, HLG 1278, UH 405, HLG 1339.Their resistance to the infestation with smut diseases amounts to $0.0-5.0 \%$. These are the lines that may be effectively studied and used to create resistant to entomophagous and phytophagous hybrids and in further breeding study.

Therefore, the significant infestation of susceptible lines with head smut was observed in terms of monoculture, and the maize cobs were characterized by heavy infestation that significantly influenced the harvest of these lines. In connection with 
this, the assessment of lines and hybrids for resistance to head smut against the enhanced provocative background is a very important step in breeding the hybrids resistant to diseases. The improvement in the effectiveness of assessing the resistance of lines and hybrids to this disease in the Right-Bank Forest-Steppe of Ukraine, where the disease is not widespread, requires the use of artificial provocative background.

\section{References:}

1. Palamarchuk Vitalii, Telekalo Natalia (2018). Vplyv rozmiru nasinnya ta hlybyny sivby na komponenty struktury vrozhayu kukurudzy [The effect of seed size and seeding depth on the components of maize yield structure]. Bulgarian Journal of Agricultural Science, 24 (No. 5), pp. 783-790.

2. Kolisnyk, O. M. (2016). Stiykist' samozapyl'nykh liniy kukurudzy do ustilagozeae I sphacelothecareilina. Selektsiya ta henetychna nauka ta osvita [Resistance of self-pollinated maize lines to ustilagozeae I sphacelothecareilina. Selection and Genetic Science and Education]. Materials of the International Conference March 16-18, pp. 134-137.

3. Kolisnyk, O. M., \& Liubar, V.A. (2007). Stiykist' vykhidnoho kukurudzyanoho materialu do kypinnya smoly [Resistance of the initial maize material to boil smut]. Feed and Feed Production, no. 61 , pp. $40-45$.

4. Kolisnyk, O. M., \& Vatamaniuk, O. V. (2010). Stiykist' samozapyl'nykh kukurudzyanykh liniy do zberihannya ta pererobky zerna [Resistance of self-pollinated maize lines to UstilagozeaeBeck Grain Storage and Processing]. Scientific and Practical journal, no. 8 (134), pp. 28-30.

5. Orlianskyi, N. A. (2005). Povedinka kukurudzy v umovakh shtuchnoho stresu, sprychynenoho perepovnennyam [Behavior of maize under conditions of artificial stress caused by overcrowding]. Com and Sorghum, no. 4, pp. 5-8.

6. Azurin, V. O. (2002). Kil'kist' kvitiv na kukurudzyaniy kachani ta yiyi nasinnytstvo [Number of flowers on the maize cob and its seed production]. Collection of Scientific Papers of the Institute of Agriculture of the Southern Region of UAAN. Kherson.

7. Ponurenko, S. H., Hurieva I. A., \& Panchenko I. A. (2005). Fenotypovyy efekt ta ekolohichna plastychnist' zrazkiv henofondu kukurudzyanoho zerna za kharakterystykamy yakosti ta produktyvnosti zerna [Phenotype effect and environmental plasticity of samples of gene pool of maize grain by characteristics of grain quality and productivity]. Scientific works of Poltava State Agrarian Academy. Agricultural Sciences, vol. 4 (23), pp. 64-66. 